\title{
WestVirginiaUniversity
}

THE RESEARCH REPOSITORY @ WVU

Graduate Theses, Dissertations, and Problem Reports

2012

\section{A Blithe Killing: Through The Mind of a Monster in Lee Blessing's "Down the Road"}

Branden Chowen

West Virginia University

Follow this and additional works at: https://researchrepository.wvu.edu/etd

\section{Recommended Citation}

Chowen, Branden, "A Blithe Killing: Through The Mind of a Monster in Lee Blessing's "Down the Road"' (2012). Graduate Theses, Dissertations, and Problem Reports. 3350.

https://researchrepository.wvu.edu/etd/3350

This Thesis is protected by copyright and/or related rights. It has been brought to you by the The Research Repository @ WVU with permission from the rights-holder(s). You are free to use this Thesis in any way that is permitted by the copyright and related rights legislation that applies to your use. For other uses you must obtain permission from the rights-holder(s) directly, unless additional rights are indicated by a Creative Commons license in the record and/ or on the work itself. This Thesis has been accepted for inclusion in WVU Graduate Theses, Dissertations, and Problem Reports collection by an authorized administrator of The Research Repository @ WVU. For more information, please contact researchrepository@mail.wvu.edu. 
A Blithe Killing:

Through The Mind of a Monster in Lee Blessing's Down the Road

\author{
Branden Chowen
}

Thesis submitted to the College of Creative Arts at West Virginia University in partial fulfillment of the requirements for the degree of

\author{
Master of Fine Arts \\ in \\ Theatre (Acting Concentration)
}

\author{
Jules Malarcher, Ph.D., Chair \\ Jessica Bishop, M.F.A. \\ Laura Hitt, M.A.
}

School of Theatre and Dance

\author{
Morgantown, West Virginia \\ 2012
}

Keywords: Acting, Down the Road, Lee Blessing, Process, Serial Killers Copyright 2012 Branden Chowen 


\title{
ABSTRACT
}

\author{
A Blithe Killing: \\ Through the Mind of a Monster in Lee Blessing's Down the Road \\ Branden Chowen
}

This document is an examination of an actor's journey playing serial killer William Reach in Lee Blessing's 1989 play Down the Road at West Virginia University in the fall of 2011. It covers everything the actor has gone through in order to find some semblance of success with the role, from script analysis, to research, and preparation. This thesis attempts to take the reader on the same mental path that this actor followed in order to step into the shoes of one of America's most disturbed, fictitious serial killers. 


\section{DEDICATION}

I dedicate this work to the love of my life, Bridgette, as well as my mom, dad, and sister. Without any one of these people, my life would be incomplete.

Also to my late grandfather, Andy, who passed away while I was writing this thesis. Thank you for your love, your sense of humor, and that crazy receding hairline of yours. You are forever engrained in our hearts and memories. We will always love and miss you dearly. Rest well, Gramps.

Finally, I dedicate this work to my late grandmother, Virginia, who passed away five days after my grandfather. You have shown me more love than I could ever ask for, always being there when I needed a free dinner at Big Boy's, a good laugh, a thoughtful conversation on politics, religion, or money, or a couch to rest on between classes and rehearsal. I could always count on you to be at my show, no matter the distance, and to boost my ego with a game of cards or Scrabble. Few people have helped shape who I am today, and who I will continue to be in the future, more than you, and I am eternally grateful to have lived, loved, and laughed with you. Rest well, Grams.

I love you all very much, and I thank you for always supporting my dreams, no matter how ridiculous they might seem. 


\section{TABLE OF CONTENTS}

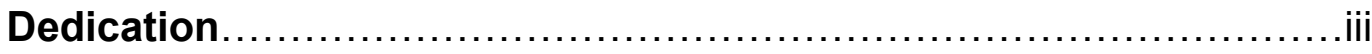

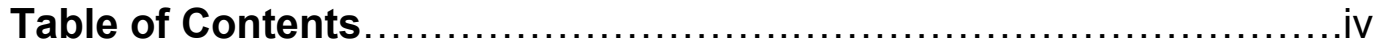

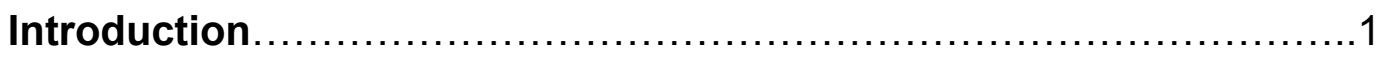

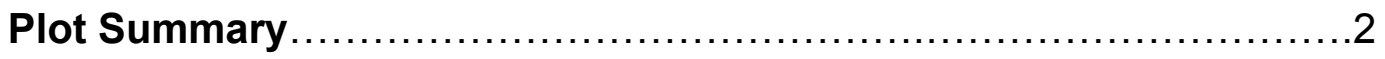

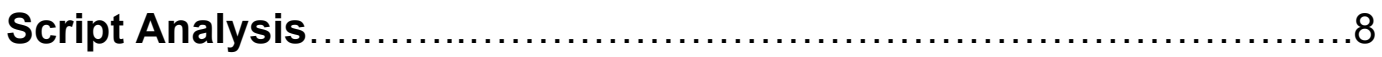

Listen and Respond

Part One: Research...............................................

Part Two: Journals and Victims ............................ 32

Part Three: Process........................................... 42

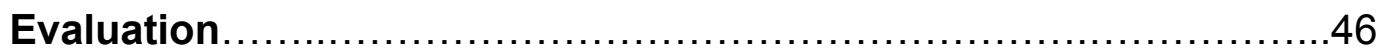

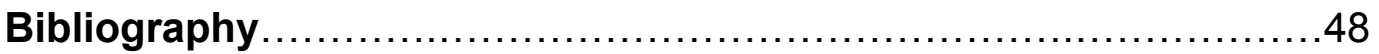




\section{INTRODUCTION}

To say that serial killers have always fascinated me is an understatement. Ever since high school, when I stumbled upon my first true crime novel sitting on one of my friend's end tables, I have been hooked on researching the lowest depths of human depravity. That first book that I found on the end table was entitled Daddy Was the Black Dahlia Killer, which, in hindsight, is a poor take on the identity of one of America's most mysterious killers: the Black Dahlia murderer. I remember picking up that well-read novel for the first time, and asking my friend's mother about it. That's when I discovered that there was this section in bookstores that contained hundreds of thousands of novels about reallife crimes and criminals. From that day on, my time spent at Barnes \& Noble would expand in folds.

I bought any true crime novel that looked interesting, and soon had a nice, large collection of gruesome stories to read. From authors Ann Rule to Harold Schechter, and serial killers John Wayne Gacy to Ted Bundy, I remained fascinated by the sociopaths that walked our streets. This fascination climaxed with a special interest course I took during my undergraduate studies at Wayne State University entitled "Serial Killers."

That said, I felt like I was primed to work on Lee Blessing's Down the Road in one way or another once I discovered that it was going to be a WVU theatre production. 


\section{PLOT SUMMARY}

In one sentence, Down the Road is the story of a married couple's attempt to write a book about William Reach, an American serial killer.

The opening scene introduces the audience to Dan and Iris, and the dirty motel room that they are staying in. It also introduces the rusty old water heater that sits on the porch of the house across the street; the couple can see the water heater from their window. We discover that Dan and Iris are about to begin interviews with serial killer Bill Reach, which they will use as research to write the book about his murders. This is Dan's first go at interviewing dangerous criminals, and Iris' first interview with a serial killer.

The audience meets Bill Reach in the second scene, right as Dan is beginning his first interview with Reach. The date is April $2^{\text {nd }}$. Reach admits to killing "at least nineteen" victims, and his manipulation of Dan begins.

Dan and Reach go on to discuss Reach's first victim, Cindy Lauterber. With a simple clarity and ease, Reach discusses how he went about finding, charming, and then killing Cindy. Afterwards, Dan returns to the motel, and to Iris. The couple discusses how Reach is trying to convince Dan he's a regular human being, in which Dan replies that he is starting to believe him. Iris then seduces Dan, and the couple agrees on trying to create a baby.

After their night of pleasure, the couple wakes up rejuvenated, trying out new baby names for the little girl they hope to have as Iris gets ready for her first interview with Reach. Once in the interrogation room, Reach reads a letter that he's written to one of his many love interests - or "fans" - outside of prison. 
Reach attempts to flatter Iris with compliments, but Iris wants nothing of it, and gets right down to the business of discussing the death of Cindy Lauterber.

Back in the motel room, Dan makes mention of the fact that Iris has been including a ton of notes about the water heater on her tapes.

In the interrogation room, the interview picks up a couple weeks later, and the conversation has moved to Paula, the fifth victim. The audience finds out that Reach kept Paula in his apartment for six days after he killed her because Reach "liked her."

Scene ten sees the progression of Iris' water heater obsession, which Dan finally confronts her about. Iris is obviously offended that he would bring it up, and insists it is just a way for her to escape the psychopathic tendencies that Reach speaks about every day. Iris also emphasizes how coolly Reach discusses all of the gruesome details, as if he were "stripping a chair."

Dan jumps back into the hot seat with Reach. Reach quickly reveals that he and Scanlon, the publisher of the book, have been discussing titles. Dan had no idea this was happening, and it definitely annoys him. The duo goes on to discuss the ninth victim, Melanie Bryce. Bryce is unique because she is the first victim that Reach picks up from out-of-state. The discovery is also made that Reach had a fiancée, but when anyone calls her his fiancée, he gets pissed off, claiming that he "only gave her a ring," and that she was not his fiancée. The details that Reach expose about this killing are the grizzliest in the play, and it has a profound effect on Dan, which is seen when Dan returns to the motel later that night. 
Dan is not the only one coming back to the motel, though: Reach follows him into the room. With Reach in the room, Iris reveals that she is pregnant, and Dan starts to show signs of wear, asking her to leave it all behind and forget about Reach. Iris shoots him down, telling him that they'd never write for Scanlon again, and saying that if they don't write the book, Scanlon would just hire someone else to do it, and they would get the fame and fortune that follows. The scene ends with Reach asking Dan a load of questions about his relationship with Iris. Dan does not respond, and it is left unclear to the audience whether or not Dan hears Reach.

In the next scene, Reach is eager to talk about his childhood, but Iris pushes the conversation to his college days, and tries to talk more about his fiancée, his education, and his previous work. This upsets Reach for some reason, and he tries to force the conversation back to the nineteen victims. Right as Reach explodes over the fiancée/girlfriend situation, Dan cuts in at the motel, discussing how Reach's childhood was relatively normal: he had a couple of stepfathers, was an only child, he spent some time in a juvenile center, and he did not get along too well with his mother, but she was not abusive to him. Then Dan waxes poetical about the highway, revealing that he dreams of leaving the motel, and Reach, behind for good. He finishes with a terrifying statistic: "In the decade of the 1950s, before completion of the Interstate, there was only one case of serial murder reported in the United States. In the whole decade, just one. Now - one a month" (Blessing, 32). 
When the scene jumps back to Dan and Reach, it is as if the conversation never paused, and Reach threatens to call Scanlon to complain about Iris. Iris slyly sways the conversation back to that of Reach's fiancée, and Reach follows along for a bit, divulging that fact that he "loved her." Reach then gives a glimpse into the possible motives behind his killings when he tells Iris, in so many words, that he will be remembered forever.

Dan and Reach are then sitting in the same bed in the motel room, watching a late night talk show. Even though Dan and Iris ignore his presence, he is still forcing his way into their life. As the conversation continues, Dan tries to talk about baby names, but Iris insists on talking about Reach and his motives. At one point, Reach storms out of the room and back into the interrogation room when Iris says something he does not agree with: that his killings are a way at getting revenge on a society that ignored him. Then Iris pleads with Dan to leave the assignment, in a complete role reversal from several scenes prior. Dan insists that this is just their job, and nothing more, and that they need to stay and see the book through to its conclusion.

The couple must have agreed to stay because Dan is interviewing Reach the next day. This time, though, Reach says that he will be doing the talking, and Dan will be listening. Reach then proceeds to discuss how murdering someone in the dead of night felt to him. He romanticizes the events, and Dan is once again affected by Reach's words. 
When Dan gets back to the motel, he tells Iris that she needs to apologize to Bill in order to make him talk again. Iris is not pleased, but she gets ready to go visit Reach anyway.

The next time we see Iris, she is interviewing Reach, who forces her to apologize. Iris reluctantly and half-heartedly does. Reach then agrees to talk about Diane McCusick, another of the nineteen victims. He talks about how he picked her up at a carnival, lured her to his car, and then hit her with a hammer and drove the body away. Her murder is noteworthy because Reach did not dump her at Sugar Lake, the usual dumping grounds. He then goes on to reveal that with the tenth victim, the last one he left at Sugar Lake, he had forgotten to grab her bracelet. So he went back to do so and finally saw the area for the first time, filled with decaying corpses. As he looked on, he claims, after some thought, that he howled at the moon. He switched sites after that incident because he was afraid of losing control.

Obviously upset about something, Iris confronts Dan about his recordings of ambient highway sounds, and then discovers that he has gotten rid of the water heater across the street that Iris had become completely obsessed with. Iris lashes out at Dan, claiming that he sympathizes with Reach. This climaxes with Dan threatening to leave Iris.

Reach then wakes up in Iris' bed at the motel, apparently post-coital. Iris admits that she thought she could handle hearing the sickest, most evil things without it having an effect on her, but Reach has changed all of that. 
Down the Road concludes with all three characters coming together in the interrogation room for the first time. Dan and Iris obviously thought they could get further with him if they both interviewed him at the same time. The conversation today is about Reach's last and youngest victim, Jeannette Perry. Reach is not interested in talking about Perry at first, though, and starts asking about their unborn child. Iris is in shock that Dan would tell Reach about that, and she verbally attacks Reach, calling him subhuman, infuriating Reach. As Dan tries to get the conversation back to Jeannette Perry, Reach and Iris go off in an argument about his motives. Dan is eventually able to get Reach to talk about Perry again, and this sends Reach out of the interrogation room and into the motel room, all the while telling his story of Jeannette Perry to Dan and Iris. At this point, he even takes his handcuffs off with no problem, dangling them about as he tells his story. The audience then finds out that he turned himself in after the Perry killing because he felt it was time to quit and announce what he had done.

Iris and Dan begin to argue once again, which prompts Iris to leave. She asks Dan to go with her, but Reach reveals that there was a twentieth victim, and Dan refuses to leave. Reach continues to reveal details to Dan about this final victim in the motel room, as Iris stands, motionless, staring on in the interrogation room, and the security guard raps on the interrogation room door. 


\section{SCRIPT ANALYSIS}

It does not matter how many times one reads Down the Road: William Reach is a disgusting character. What makes him so evil is how calmly and coolly he discusses everything. Whether he is talking about the title of the book, or how he brutally murdered a ten-year-old girl, there is a calm, carefree demeanor about him that can be more accurately described as sociopathic behavior. What is utterly fascinating about the script, though, is the different levels that Blessing creates. On the first read of the play, the cast and I thought we were working with a solid script. Then, as we started working on our feet, some of the weaknesses of the dialogue sprang up, mostly between the characters of Dan and Iris. Finally, after more digging and more justifying, the brilliance of the script started to shine through, and the actors, myself included, started to question whether or not our justifications for certain moments were actually what Blessing intended. A while later, we realized that it did not matter, and just got back to listening and responding.

Looking at the script from my perspective, as the actor playing Reach, there was less to be concerned with when it came to justification; Blessing included most everything I needed to motivate my actions.

The audience's first introduction of Reach is also Dan's first meeting with the killer. The first spoken lines of live dialogue - because Reach's first three lines are actually recorded dialogue, according to the script - feel like Reach is interviewing Dan for the job of researching his killings:

Reach: "What's your name again?"

Dan: "Dan. Dan Henniman." 
Reach: "Ever write about someone like me, Dan?"

Dan: "No. But my wife-“"

Reach: "The publisher - Mr. Scanlon - said you write for Business Week?"

Dan: "I used to. Now Iris and I-“"

Reach: "I don't mean to criticize. It is just that I want to get the story told. The best way."

Dan: "Certainly." (9)

This immediately tells us that Reach wants to have the control, which is a theme that repeats itself throughout the entire show. When Reach is in power in control - things go smoothly for everyone. Otherwise, Reach will lash out, threaten, and would probably kill if he was not in handcuffs. In Reach's first scene alone, the character begins to control, manipulate, deny information to his interviewers, and threaten. These are important traits that manifest themselves in different ways through the whole play.

This dialogue is actually a wonderful representation of the importance of looking at ellipses and dashes, which is something that the director stressed to us. Normally in scripts ellipses represent a trailing off of thought, while dashes represent a cutting off by another character, or even an internal cut-off. I found this to be the case here as well. Blessing puts in a lot of these clues throughout the script, and if the actor abides by them, the dialogue can easily flow naturally. This dialogue presented above is just one of many different examples that support this idea.

In scene four, Reach's second scene, Reach begins telling of his murders for the first time. There is a smug arrogance about every detail that is slightly veiled by his demeanor; he looks, sits, and talks like an everyday guy, thus he appears "normal." That normalcy starts to fade a bit with every detail of his first 
murder. Reach answers how he picked up Cindy Lauterber - his first victim with a simple and effective answer: "She was pretty. I told her I was a magazine photographer. Asked her to come out to my car so I could take a couple pictures - show my editor" (11-12). In his mind, it was a simple cause and effect. She was pretty, so he did this, as if it was the natural way of things.

This is also the first time we see unveiled intimidation by Reach. Dan tries leading Reach into a series of questions about his sex life, which Reach obviously has no interest in. There is a quick beat change after Dan's question that sees Reach try to turn the tables on him, and Reach telling him that he thinks he "know[s] a lot about this" (12). The question that I asked myself in this moment was does talking about sex bother Reach, or does he see it as a weakness in Dan? Reach clearly sees Dan as someone that he can control and manipulate because he has already done so within their first hour of interviews, so this could be just another way that Reach gets the power back into his own hands. In fact, the next scene sees Dan admitting to Iris that Reach is "straining at the seams to convince [him] he's human," and "what's scary is, he almost can" (13). Here the script tells us that Reach's manipulation of Dan is starting to work. The first time Reach meets Iris, he is reading a letter that he wrote to one of his female "fans" outside of prison. Since we will later learn that Reach used to be an English major, it tells me that Reach is trying to impress Iris - a writer herself - during their first meeting using a skill that he thinks he has. Unfortunately for him, the letter is not poetry, and his attempt to impress Iris with his writing fails. Like any good character, he tries something else; this time, 
flattery. He tells Iris that he's read all of her books, and that she is very good (16). When Iris' response is a short and quick "thanks," he tries something else: "You never have a picture on the jacket. You're younger than I thought. Prettier" (16). It has already been established that Reach is a charming guy, which is how he almost always attracted his victims, so he is doing his best to try and charm Iris, who has nothing of it. She replies with "so are you," and then gets right down to the business at hand. Reach is clearly upset by this because he immediately starts to give her the silent treatment. Iris has won this first battle of power, and Reach does not like to lose.

Later in the scene, after Reach starts talking about his victim again, he shifts immediately from how he killed Cindy, to asking if Iris is afraid of him (17). There is something that Reach is not getting from her that he wants, and so he tries to surprise her with quick intimidation. Iris does not bite, answering "desperately. What happened next?", and the conversation is back on track. The war of words between Reach and Iris is established quickly.

There is a small line at the end of this scene that is as revealing as anything else that Reach says. When Iris asks how he felt while he was driving home after dumping Cindy's body, he replies, "like God" (17). This was a key line for me as I was preparing every night, and one that always resonated as a statement of truth from Reach. This is why he killed, and why he tries to manipulate Dan and Iris: he wants the power. Who has more power than a God? He wants to be as powerful, and as feared, as God. 
The Iris and Reach conversation picks up in scene nine a couple of weeks later. Iris is quickly given a position of weakness by Blessing when she accidently asks about Cindy's body instead of Paula's body, which Reach catches immediately. He starts to patronize her because of her mistake, and feels good about himself because he is once again in control. This level of comfort Reach feels continues through the scene, and it culminates with him hitting on Iris. When Reach is telling how he chose his victims, he says that "even just her clothes" could help him decide to kill her or not.

Iris: "Skimpy clothes? Expensive?"

Reach: "Just nice. Nice, clean look. Done up, not careless. l'd see a girl like that and want her.

Iris: "Why didn't you just have her?"

Reach: "What?"

Iris: "You were single, good-looking. You probably could've gone to bed with a lot of these women."

Reach: "Sure, but what's the point? That wouldn't've been different from what anybody else does." (19)

This small beat goes through a lot of different changes. The first is Reach hitting on Iris as he describes exactly how she looks for this interview: nice, clean, and done up. Then, Iris plays along a little bit, even calling him attractive. Reach takes the prize for the battle, though, when he says that if he just had sex with Iris, or the victims, then he wouldn't be special; anyone can have sex with Iris or his victims, but what he has done, or could do, to them is special. This is a big win for Reach, and Blessing writes in a beat change after the final line, and then Iris needs to sway the conversation into a completely different direction to try to get past this bizarre moment. 
Scene ten sees the first shift from total realism, and it ends with a moment that would make for a wonderful montage if Down the Road were ever adapted into a film. Iris and Dan are arguing about the water heater, and Iris says "with most murderers it's, 'I hated this, I hated that, I hated everything.' With Reach, it's just...a wall. 'Why did you kill her?"' (22), and then Reach replies from his interview room with "I don't know." The next eleven lines in the scene are a conversation between Reach in the interview room and Iris, who is actually talking to Dan in the motel room. This shows that Reach is starting to infect her mind, so much so that his voice his pitch perfect in her mind. She ends with a telling element of Reach: "He could have been stripping a chair" (22). She admits that Reach is getting to her, and the lights go out.

Scene eleven picks up with another letter, but this time it is one Reach has received and Dan is the listener. The woman tells him that he has a "rare quality of charm not even the man on Sixty Minutes can refuse" (23). This tells the audience, if they did not already see it, that Reach's charm is real, and not all in his head; women actually find this man attractive. The lady even sends her picture, which was a beautiful young woman in a bikini in our production, which plays on the sexual desires of all three characters. Dan asks to look at the picture, and Reach gladly allows it. Blessing tells us that "Dan stares from letter to picture," which Reach notices. Reach then cuts the silence with "she's cute." Dan, taken out of his staring gaze, stumbles a little bit with "what? Oh... Let's get to work" (23). Reach senses that Dan is attracted to the woman, so he does his 
best to take advantage of that by making Dan uncomfortable. Reach's expert manipulation is in full effect.

This scene is an important one because it puts Reach entirely in Dan's head, which will manifest itself in the following scene. It is also interesting to note that this is the longest scene in the show, running just over four pages.

After the moment Dan is made uncomfortable by Reach, Reach then sways the conversation immediately to the title of the book. Here we learn that Scanlon has been discussing titles of the book with Reach, asking his input, which neither Dan or Iris knew anything about. It irritates Dan, but he turns the recorder on and tells Reach that he would like him to talk about Melanie Bryce.

Though the scene is filled with gruesome details about the capture and killing of Melanie Bryce, there are a few other important moments that deserve analysis. The first is that of the introduction of Reach's fiancée, Donna. Reach is adamant throughout the play to state that he "gave her a ring, that's all," and that because they never set a date for marriage, she was never his fiancée. For my money, if someone proposes to someone else, they are then engaged, and thus, have a fiancée. For some reason, Reach does not see it this way, and is quick to get off the subject. It is one of Reach's only vulnerabilities throughout the play, which makes it important for the actor.

If Reach admits that he lost his fiancée, that makes him look weak and pathetic, thus he loses power, and the book that is being written about him cannot portray him in that light because it is how society will look at him for the rest of eternity. To make up for this loss - this weakness - he makes himself 
believe that she was never his fiancée, and that she did not dump him, which will be revealed later in the show.

A second point that comes up in this scene is that of blame. Without explicitly saying that it was the girl's fault they were killed, Reach says, "it was raining. Real downpour. They stuck their thumbs out" (24). This tells me that Reach thinks it was their own fault because they stuck their thumbs out and asked for a ride. If they hadn't done so, then he would never have picked them up. This is supported by scene earlier when Reach is talking about the randomness of his victim selection. He did not seek these girls out; instead, they fell into his lap, or car in this case.

There is a strange moment in the scene that sees Reach trying to skip over some facts. Reach says he drove Melanie to Sugar Lake, but Dan steps in, and we find out that Reach took her to an empty farmhouse before Sugar Lake (25). It appears that Reach wanted to skip the farmhouse fact, but it is not made clear why that would be. The conversation then turns to the goings-on at the farmhouse, which are all sexual in nature. As soon as Dan brings up the sex, Reach tries to turn the tables on him again, and an extended battle of words goes back and forth between the two until finally Dan stands his ground and gets an answer out of Reach: "I came in her mouth and killed her. Bim-bam. Next question" (26). Reach is quick to get over the sex talk, but revels in the details of the murders.

The discussion of Melanie Bryce obviously has a profound impact on Dan, and the fact that he can't get the story out of his head manifests itself by Reach 
following him into his motel room. Dan admits that this story was the worst one yet, and then tries to escape the motel room - and Reach - by going out to eat. $\mathrm{He}$ is stopped in his tracks, though, when Iris confesses she is pregnant. Reach is in the room to hear all of this, even if only symbolically. There is an important moment in this scene where Dan pleads with Iris to leave, which is the reverse of how the play ends.

This scene ends with a monologue from Reach after Iris leaves the room. In the monologue, Reach asks Dan if he has a good marriage, and shows concern that the couple is staying in such a dingy motel. He says it is not "good enough. Not if you're working with [him]" (29). Then Reach gets closer to Dan and asks him directly, "Does your wife excite you?" Blessing tells us in the stage directions that "Dan shifts his gaze to Reach," which gives the audience the idea that Dan has heard this, which is clearly impossible.

Iris and Reach reconvene in scene thirteen, and Iris once again tries to push the conversation in directions Reach does not want to go. When Iris starts to talk about Reach's failings when it comes to job, Reach, "with sudden force," says that he's "not here to talk about jobs" (31). Immediately following this, Reach tries once again to regain control with a threat: "I kill women, you know." Iris responds with "not anymore," putting him back in his place (31). When this does not work, he tries a threat of a different kind. Reach says, "Does Scanlon know you're asking me a bunch of irrelevant questions? Do you want me to call him?" When physical threats will not work, he resorts to a schoolyard-type of threat with tattling. He will do anything he needs to in order to gain the upper 
hand, which he then loses when he explodes on Iris after she brings up his fiancée at the end of the scene.

Dan's monologue in scene fourteen is important for the actor playing Reach because it describes how relatively normal Reach's childhood was, as described in the plot summary.

Scene fifteen is a continuation of scene thirteen, and Reach has reached the end of his patience with Iris. When the conversation turns back to Donna, his fiancée, Reach tries to set the record straight:

Iris: “...Donna and you broke up - for the first time, anyway - not long before you killed your first victim, Cindy Lauterber. Is that right?"

Reach: "So?"

Iris: "Some people theorize that the trigger for the first time you went beyond rape and killed was Donna's rejection of you."

Reach: "Who thinks that?"

Iris: "A number of people. Is it wrong?"

Reach: "A.) She did not reject me; I rejected her. B.) Only after I rejected her did she reject me. C.) After we rejected each other, she crawled back to me and not vice-versa. And this happened several times."

Irish: "So it has no relationship to any of these crimes?"

Reach: "Why should it? She was just my girlfriend." (33)

This part of the conversation concludes with Reach admitting that he loved

Donna. The question that this brings to mind is that of justification. Why does

Reach feel the need to shoot this theory down? Is it out of love for Donna? Is he trying to protect her from getting a bad name? If he killed because she left him, then that could make Donna look bad, and almost guilty (in his mind at least). The answers could be any one of a million possibilities, but the one that fits best for me is that if Reach is pushed to kill because he lost the woman he loved, that makes him look weak, and, in a way, average. He shoots down this theory 
because he wants the world to believe that he killed "just because," which makes him even more of a monster, not because he was genuinely heartbroken. Reach seems to look out only for himself, and this justification helps solidify that observation. His admittance of love for Donna, on the other hand, plays into the vulnerability and three dimensionality of the character, making him memorable and enjoyable to play from an actor's standpoint.

The end of scene fifteen is important for Reach, and the play as a whole.

Reach, after playing the silent game again, gives an excellent insight into his own mind:

Reach: "Who are you?" Irish: "Iris Henniman."

Reach: "And in a hundred years, who are you going to be?" Iris: "Dead - that's who l'm going to be."

Reach: "That's right. But I'll still be William Reach. Why do you think you're not writing about the guy who killed his family anymore? Or the guy who went berserk with his M-16? Don't talk to me about identities. You've got a chance - just a chance - to be somebody here. Stick to what Scanlon pays you for."

Iris: "What Scanlon pays me for -" Reach: "What Scanlon pays you for is to write my book! Mine! Why doesn't matter. I did it - other men didn't. Besides your theory is shit. I killed someone before Cindy Lauterber. She wasn't the first." (34)

Not only does Blessing reveal that Reach is, in fact, telling his story so that he'll go down in infamy and be remembered forever, but Reach also reveals that Cindy Lauterber was not his first victim, which he has never admitted before. A breakthrough like that could be huge for Dan and Iris, but Reach refuses to talk anymore about it, insisting, "it's for the sequel, bitch" (34).

In order to show Reach's effect on Iris and Dan, when the lights come up on scene sixteen, Reach is on the bed with Dan, watching television as Iris 
enters. This time, Reach talks to Iris in one-word sentences that she clearly does not hear. Reach gets upset when Iris starts giving her theory on why Reach killed. She hypothesizes that because he was a quitter at everything in life, he somehow got the idea that the only way to really succeed in life was to become famous; otherwise, she says, you don't exist. His young, middle-class victims weren't real for Reach, they were just "society's prizes" (36). He would grab the prize and have his revenge on society by killing its prize. It is when Dan chimes in with the theory that he rejected killing one girl because she was too poor and did not represent the right social class that pisses Reach off enough to storm out of the motel room and back to the interview room.

The theory that Dan and Iris reach is absolutely spot-on, which is why Reach runs away: it hits too close to home. There is no way he's ever articulated the justification of his actions to himself, and when he hears this, it terrifies him, and the only way to save himself is to leave the room so he cannot hear it anymore.

Scene seventeen takes place about one month after the first interview, and it is the climax of Reach's attempts to take over Dan's mind. Reach decides that he is tired of the conversation being steered in directions he does not want to traverse, and that, on this day, Reach will lead the discussion. He decides to explain to Dan how it felt to kill these women. In a monologue that is poetic as anything Blessing has written in Down the Road up to that point, Reach dehumanizes the victims, shows how the world accommodates to him when he is God, and makes Dan a part of the entire fantasy. Reach admits things he has 
probably never spoken before to Dan, all in an attempt to get the final grasp on his mind. He calls the killings logical, and seduces Dan with talks of power, darkness, and silence.

If there is any question whether or not Reach has taken complete control of Dan's mind at the end of the scene, those doubts are squashed in the next couple of scenes when Dan forces Iris to apologize to Reach in scene eighteen, and when we discover that Dan has effectively murdered the water heater that Iris loved so much in scene twenty

Before the murder of the water heater, Iris gives her half-hearted apology to Reach for working him up, and then the two go on yet another battle of words. Whenever Iris tries to humanize one of the victims, Reach does the opposite, calling them "bodies," or simply by their numbers. The scene concludes with what looks like Reach's first lie, or at least, his first embellishment. Instead of merely "having an urge" to howl like a wolf, he claims that he did, in fact, howl, and that it would be good in the movie, too. When Iris pushes him to tell the truth, he concludes that he did howl (43). It is clear by Blessing's writing that Reach is making this up, and Iris knows it, even though there is nothing she can do about it. Why he decided to add to his story is right in the language: he wants to make it more entertaining, and thus, more sickening and memorable.

After Dan admits to Iris that he got rid of the water heater, essentially killing it, Iris wakes up in bed with Reach. The two start to kiss before Iris realizes who she is in bed with, and then jumps up. This is more evidence that Reach has ultimately taken over Dan. He has done such a good job that Iris is starting to feel 
the effects of his symbolic abduction. Reach has won in this scene, and there is nothing left for him to do but watch the show, which he will do in the next scene. Iris even admits that she could deal with the sickest things on the planet until she met him, which is the cherry on top of Reach's victory sundae (46).

The final scene in the play is almost a continuation of the energy and mood for both Iris and Reach from scene twenty-one. Dan and Iris decided to join together to interview him, which cracks Reach up. He starts laughing, seemingly because neither of them can beat him one-on-one, so they need to try it as a tag team. Reach eventually reveals to Iris that he knows all about the baby. The audience already knows that Reach knows about the child, though, because they saw Reach in the room with Dan and Iris when Dan found out the news. Having Reach in the room during that scene - scene twelve - works on two levels: it tells the audience that Reach has begun infecting Dan's mind, and it also cuts out a scene that might be needed otherwise where Dan tells Reach about the baby.

When Iris says that Reach is no better than any other "species that preys on the untended young of its own kind," Reach snaps (48). He does not want to be called subhuman, because if he is not human, than his story is not special. It would be just like a bear mauling women: tragic, but not nearly as memorable. It is imperative for Reach that he remains an average guy because that is what makes his acts so vicious, and more importantly, so memorable.

After Reach explains to Iris how many kids are born in the United States every minute, Dan turns the conversation back to Jeannette Perry, the ten-yearold that Reach killed last. When Reach begins to talk about this killing - and 
messing up the facts of the story - he takes his handcuffs off and heads for the motel room. Instead of sticking to the original story he told of Jeannette, Reach insists that he lied in court to make the case "simpler" and "easier on everybody" (49). He then proceeds to go into a monologue that feels like a free association game for him: whatever pops into his mind, he says as fact. When Iris points out that he said Jeannette had blue eyes when in reality they were brown, he is nonchalant about the whole thing. "So I forgot. It doesn't prove anything" is his response, smiling all the while (50). This proves that Reach does not care at all about his victims, just that he creates a good story, and he loves the fact that Iris can do nothing to stop him. He knows - just as Dan and Iris have pointed out earlier - that if they leave, he'll just get another author in, and his story will be told the way that he wants it to be told.

Reach's last-ditch effort to get Iris back into the case after she says that she is leaving is his admittance that he killed a woman named Renee Michaels. Reach says, “You didn't think l'd leave you high and dry? I'll add a new killing. Got to sell this thing. There's plenty of competition out there" (52). Whether or not this killing is a fabrication or a lie does not matter at this point, because Dan believes Reach, and allows him the opportunity to tell his story as the play ends.

The major themes of Down the Road are evident in all three characters: power, love, trust, and fame. Each of the three characters goes through all of these themes in one way or another, and there are virtually no questions answered at the end of the play. The Sopranos-like ending may not be fulfilling, but it plays well with the theme that, no matter what we do, and how blind an eye 
we turn to it, there are people in this world who kill. Their motives are unimportant, and the results are devastating. It does not matter if we write the story, or if someone else does, these killer's stories will be told, and then a hungry public will consume them. 


\section{LISTEN AND RESPOND - PART ONE: RESEARCH}

One thing I have learned in my time as an actor on West Virginia University stages is that no matter how "easy" a part may appear at first, when you really start diving in and begin discovering motivations, wants, and needs, every character - no matter how small, and I have played a lot of smaller roles in my time to justify that flowery sentiment - is a challenge. What's incredible, though, is that no matter how easy or hard a character may appear, whatever that really means, in the end the road to success is always paved with genuine listening and responding. It is just that simple, and that difficult.

With William Reach, in order to find that simplicity that the role required, I was forced to look inwards and go to dark places that I may not like; finding the "me I didn't know," as Professor Jerry McGonigle would preach. Fortunately my years of unintentional research into playing this character helped me right from the first - and only - callback where I read for Reach. It is funny because I actually read for the character of Dan three or four times before asking the director, Kara Haas, to give Reach a reading. Kara must have seen something she liked because the other two actors in my callback were Greg Jernigan and Amy Byrne, both of which would be cast along with me in this production.

Although Kara cast the show with the three of us, she took a week or two to make the final decision on who would be playing Reach and Dan. While we were in limbo, I honestly expected to play Dan because he is more my "type," but was pleasantly surprised to get the chance to play Reach, a character unlike any I have played before. 
Though not much time was spent with the character of Reach over the summer before rehearsals began, my previous studies of serial killers gave me an understanding that what makes these individuals so scary, and in turn, so fascinating for some people, is that they do not appear abnormal in any way. For the same reason that Hannibal Lecter is scarier than Freddy Krueger could ever be, I understood immediately that if I attempted to make Reach scary in any way, it would be doing the character, the show, and myself a disservice. The only road to success with Reach, right from the start, was to keep reminding myself that he was a human who happens to rape and murder, rather than approaching him as a monster who happens to be in human form.

Everyone knows what is said about the "best laid plans," though, and as simple as I thought that approach would be, I immediately started to get in my own way. I was trying too hard to act like a serial killer, playing scary and maniacal, instead of just listening and responding, and the result of this was a hunched over lunatic that the audience would never be able to see because I was so closed off. One of the first notes that Kara gave me was to follow a celebrity's mindset instead of a killer's mindset. This, to me, justified my initial ideas that I cannot play a killer, but need to play a man, who happens to kill. The difference might seem slight, but it put me in a different thought process completely, and greatly altered the character.

Once the first week of rehearsal began, trying to find real interviews with serial killers on YouTube began as well. One that stood out immediately was Edward Kemper, the "Co-ed Killer." Kemper is fascinating because he is one of 
the more notorious serial killers from the early 1970s, yet he is still liked by virtually everyone that meets him. He has a calm and endearing demeanor about him that immediately makes him a likable fellow, which certainly aided his killings. William Reach is comparable in a lot of ways. The script tells me that Reach was interviewed on Sixty Minutes, has multiple books written about him, and even has a t-shirt made in his honor; Reach is nothing short of a celebrity, and people tend to like celebrities. Reach also writes and receives notes to and from beautiful women, much like Richard Ramirez, the "Night Stalker" who killed in Los Angeles, California in the 1980s. Ramirez was actually married in prison, which is something that could happen for Reach in the future. All of this information gathered during the first week of rehearsals quickly steered me out of that "play a serial killer" mentality.

On advice from Kara, I even checked out some interviews with Bradley Cooper (from The Hangover), who is considered one of the more charming celebrities out there. It is hard to pinpoint exactly what I took from watching his interviews, but one thing that stood out to me was the obvious fact that charming people are born that way. Charm is not something that you can fake or learn, it is just something that some people are born with, and William Reach is one of those people who just happens to know how to use his charm to his advantage.

In order to research some interrogations during that first week, I also watched an ABC TV show entitled Take the Money and Run. This show pits two regular people against two professional interrogators and two detectives. The two regular people hide a briefcase filled with money in whichever city the show is 
filming that week. After they hide the money, they are taken into custody, and if they can keep their mouths shut for 48-hours, then they get to keep the money. If they break under the interrogations, then they lose the money. It is a simple premise, but it gives the average viewer an idea of how stressful interrogations can be. Though Reach is not being interrogated in Down the Road, there are still similar themes and stresses that Reach goes through while being pushed by Dan and Iris for more information. These stresses reveal themselves at the times when Reach explodes, mostly on Iris, because the conversation gets too personal.

That first week of rehearsal was a breeding ground for new questions, and to keep everything on track, I decided to write out my thoughts in journal form, and labeled it Journals and Victims.

We really started putting the play on its feet during the second week of rehearsals when we moved into the theatre. One thing that I continued to struggle with was trying to keep myself open to both the audience and my acting partners. In order to help with this, Kara changed the position of the table a bit, and moved my seat to face directly out to the audience instead of towards my partners. This helped a great deal because it forced me to spend the majority of my time looking at the fourth, imaginary wall, which translates to me looking out into the audience, instead of keeping locked into a stare with my partners. This not only affected my character - which could be calmer and more in control from this new position - but also helped with my vocal quality. Instead of hunching over and blocking off my voice, I was open and free to produce as much or as 
little sound as I wanted. This simple turn of the chair and repositioning of the table was incredibly freeing, and my initial fear that I wouldn't like the new spot quickly vanished.

One evening, after we had run a section of the show, Kara did private meetings with each of us, asking us questions about our character. I took a page of notes during this session, which helped a great deal in finding out who Reach really was. Here is that page of notes, transcribed in their original form:

"William Reach: Easily hits on girls. Long fuse, hot temper. A dark side that I am comfortable with. Open, but rarely puts anything precious on the line. Could be neglect - reinforces the need for attention. Detachment from humanity - see how they work on the inside.

"(Serial killer Gary) Ridgeway has a possible first victim; has memory of a murder of a boy in water. Could this be any relation to me? First murder is different - could be more personal.

"Very aware of social norms in college.

"Unambitious jobs - I can feel superior. If I try my hardest and fail, then I am really fucked.

"I'm really good at the interview/celebrity game. Iris pushes me harder - could be exciting. I respect someone who is good at their job.

"I'm a great serial killer. Maybe I thought this up beforehand: thought through killings, story arc, interviews, and fame. Have my life story planned out, potentially. I plan out my immortality. "Do girls turn me on, or do I just like that they throw themselves at me? That they give themselves over to me?

"Dan is Iris' weakness. I can control Iris through Dan.

"Another connection to Bundy - losing my girlfriend makes me snap (potentially)."

This page of notes was one of the most influential pages of notes that I took throughout my time as Reach. So many questions were opened up to me, which is much more important to my character progression than any answers could be. 
The final note about Ted Bundy is of utmost significance. I spent a great deal of time researching Bundy, who is one of America's most notorious serial killers. There are a lot of connections between Bundy and Reach, and I think it might have to do with the fact that Bundy was coming back onto American televisions screens in the late ' 80 s, when Blessing would have been writing Down the Road, because he was executed for his crimes in 1989. The heinous acts that Bundy committed must have been all over the news once again in the weeks before his execution, and Blessing, as someone who was obviously interested in serial killers, probably took notice.

Whether or not my theory is accurate, I was able to find a good amount of connections between Bundy and Reach: both Reach and Bundy refused to give details about their first killings, both had a fiancée before they started killing, both are noted for their charm and attractiveness, and both used the interstate to their advantages in order to find and kill women successfully. What do these connections mean? Very little in terms of practical application, but it is always better for me when I can relate my characters to reality because it helps me connect easier.

One of the more gruesome and unfortunate bits of research I thought would help my playing of William Reach was to search for real murder scene pictures. As much as I love gory horror films filled with blood and guts, I cannot stand seeing real crime scene photos. But, because Reach has created these horrific scenes so many times in his life, I felt it was important for me to see these photographs in order to help me understand just how much carnage a gunshot, 
or multiple knife wounds can inflict. The research genuinely made my stomach churn. The brutality that human beings are able to commit on each other is disgusting and disturbing. More directly related, the acts that William Reach committed are one thing to think about, but something else entirely when you actually see a victim who was decapitated by a fishing knife, or a hammer, for example. These images are some of the most disturbing things I have ever seen in my life, but they helped give me a literal and specific understanding of what Reach was capable of doing, instead of an unclear "he can do bad things" approach.

The power that Reach must have felt physically when committing these acts was not something I could really relate to when this process began. Personally, I have never been in an actual fistfight, and have never even punched someone out of anger. It is just not something I have encountered. In order to help me find the physical edge that Reach must have, Kara decided it would be beneficial to teach me some mixed martial arts. So one night after we ran a section of the play, Kara pulled out some blue tumbling mats, and she taught me a few moves that she knew from her training, and with the understanding that neither of us would hurt the other, and we would stop as soon as one of us asked to stop, we began sparring on the mat. This immediately showed me how much power it takes to hold someone down, which Reach was accustomed to doing. Kara, who is much lighter than me and extremely quick, was not easy to keep pinned to the mat. Not only was it fun to try and beat up my director, but it was also quite effective in that it showed me what I was physically 
capable of doing in order to keep someone pinned down. It opened up my physicality in a way I had never experienced before.

One of the final pieces of research I did to help me fully realize the world that Reach was living in was a victim sheet I created during the first couple weeks of rehearsal. I decided to go through each victim that I talk about specifically in the show and write down every bit of detail I could about her as described in the show. This list can be found in the section labeled Journals and Victims.

It is incredible how much research can go into a character that might have no noticeable effect on how the character is portrayed, and I feel like I did a lot of that for Reach. That is not to say that all my research was in vain, because it was not, it just means that along with the practical research, I also spent a great deal of time feeding my personal serial killer fascination. The reality of the situation is, though, that I am sure every article I read, and every connection to other serial killers I managed to make, probably did influence my choices while I was playing Reach every night, making every piece of research important in its own way. 


\section{LISTEN AND RESPOND - PART TWO: JOURNALS AND VICTIMS}

During the first week of rehearsals for Down the Road, there were so

many questions coming from the readings that I decided it would be best to keep a journal for that first week. This section contains all six of those journal entries. In order to show my thought process of approaching Reach, these have been left unedited, and are presented in their original form on the following pages.

\section{Journal \#1 - Monday, August 15, 2011:}

Today was the first day of rehearsal. Finally out of the summer rut, and ready to work on a beefy role, we all met up and did the usual introductions and greetings. We got a look at the design presentations as well. The costume l'll be wearing is a bright orange jumpsuit. Luckily I have no costume changes, and everything is pretty simple. I'll obviously have my handcuffs as well. The set looks great. The designer is going for a claustrophobic feel, which is perfect for a play that takes place in a motel room and an interrogation room. This gives both places a sense of being locked up, which works with the themes of the play well. The lighting design works to differentiate between the two places: the jail cell will be cool and bright, even including a fluorescent light fixture over the interrogation table. The motel room will be warmer colors, featuring a lot of orange and brown tones. When I am in the interrogation room, I will stand out because of my bright orange jumpsuit, and will sort of blend into the motel room. It looks like a great idea, and I am hoping the execution is just as smooth. Sound did not have a whole lot for us today, but I am interested to see what we do with the tape recorder. 
After the presentations, we went into our first read through. We decided that marketing the play as Reach's story is incorrect because the play is about Iris and Dan's marriage. Reach is just a factor in that marriage. Kara used the phrase "Reach is like the dog," which I think is an interesting analogy and image that I can play with. We also decided that the first 5 written scenes are really the whole first scene of the show. For research, Kara would like me to find pictures of real serial-killer victims to use as my victims in this play. We also discussed the idea that I am the All-American boy, and the fact that I am so normal is what makes me scary.

After rehearsal, I went home and spent a lot of time on YouTube. I have a whole playlist of videos that I think are helpful in helping me understand this character of Reach better. One discovery I made tonight was in finding Ed Kemper, the "Co-Ed Killer." The people around him like Kemper, even though they all know he is a serial killer. He just has a likeable personality, which is great character work for Reach. The "Night Stalker," Richard Ramirez, is another great example simply because of his charisma, and his rock star mentality. This rock star attitude is one that I can try for Reach because I am a celebrity (even having a t-shirt).

\section{Journal \#2 - Tuesday, August 16, 2011 :}

We read through the play a couple more times today. Questions raised today: where did it come from that killing was a career option? Why do I think this makes me successful? The fame? Notoriety? We also talked about a TV 
show called Take the Money and Run on ABC that has interrogators questioning innocent people on where they hid a briefcase. This was great to see how they handled talking to each other. I think that Reach is really doing the questioning at points, in order to manipulate those around him, so I want to try and use some of those tactics on Dan especially; specifically the tactic of invading his space as I close in on him.

\section{Journal \#3 - Wednesday, August 17, 2011 :}

Today we began "unpacking" the play. We made it about halfway through the show, going very slowly in order to truly understand what each and every scene is about, and asking questions to discover what each moment is about. It is incredible how many questions are brought up, and they are all important to understand what Reach is going through in every specific moment of the play. I have decided that I need to find out the specifics of Donna and Reach's relationship. Why is it important that she was only my girlfriend and not my fiancée? Kara asked us to think about where we start each scene emotionally, and to watch where Blessing puts in ellipses, and where he uses dashes. We talked about trying to appeal to her as a writer at the beginning of scene 7 , and even playing with making the audience think I am talking to her at the start of that scene, instead of reading from a letter. It is interesting to note when and why I decide to answer her questions: I answer some "feeling" and "why" questions, but not others. Why? In Scene 9, we decided that her fuck-up is important for my mind games, and I can't let it slide. What would it mean to lose to a woman? What games can I win? 
I discovered after rehearsal that I say that I am "finally" talking, that means this is the first time I am doing this, discussing my killings. Does the topic of sex bother me, or do I think it is a weakness in him? I also need to figure out which moments I have scripted and prepared, and which moments are new to me, or are ones I am coming up with in the moment. I was also asked to find people that I think are charming and use them as character work.

\section{Journal \#4 - Thursday, August 19, 2011 :}

Today we began using the environment. Kara and Morgan [Omdal, stage manager] set up the taped stage and rehearsal furniture, and we started moving slowly through the first (5) scene(s) in the play. This was great because it gave us a reality check about just how small the space actually is. Coming from plays like Grapes of Wrath and Julius Caesar, where the set was rather large, to this is quite a difference. It is great in helping play with that sense of claustrophobia, though. Kara asked for me to slow down my speech in order to help manipulate them better. This is always a difficult task for me since I am such a quick speaker, but will absolutely help me in better achieving my goals.

In my second scene - scene 3 - Kara decided to give me some things to play with. She is toying with the idea of giving me a cigar and a bottle to drink from. Today, I had three balls, and an old scarf-looking thing. As an individual, I am very fidgety, and always have my hands going, which is why I adore having props to play with on stage. This helped put me at ease, and even gave me the feeling of power that I was missing before. Kara reminded me of that rock star mentality, and I need to play with it even more going forward. Going through the 
scenes so many times helped not only with memorization, but helped define my goals more. Nothing is set in stone; it is just good to be playing toward goals already. Listening and responding is what this entire play is about, so it is like one, big Meisner exercise.

Speaking of Meisner, I hope to, this weekend, sit down and apply some of the techniques we learned last semester to this character. Once I am able to find my notebooks that contained that information, I will do so in order to find out what it is exactly that I want more than anything.

\section{Journal \#5 - Friday, August 19, 2011:}

We picked up where we left off yesterday on our slow move through the play. We worked scenes 6 through 11. A lot more questions were posed today, and this felt like a great day for character progression. At the top of scene 7, I can play with welcoming this woman in. I am a celebrity, and I genuinely like her work. I am showing off my writing ability to this professional writer, and she just slaps me in the face, and keeps going. Let that affect me. That's when "shit gets real," and it is time to play the game.

I must constantly remind myself to try and slow my pace down. Maybe I can play with keeping things at a normal pace at points, and slowing down when I am trying to manipulate them; or quick with Iris and slow with Dan?

In scene 9, I say, "most people don't torture what they hunt." I played with the idea of the inner monologue being "most people don't torture what they hunt, but you do (torture me), you fucking cunt." This bred interesting results that I want to play with further. We also discovered a great moment where I can 
actually be hitting on Iris: how is she dressed? Exactly how I describe I like my women.

Scene 11 is big for imagery. I am going to put together these images in a slideshow format so I can think back to them when going through the scene. More importantly, I need Dan to see these images. I want to make him vomit. I want to force him to go through each and every kill to see the logic of it all. I can never give him any easy answers.

Kara reminded me that I shouldn't be too blasé about the killings as I describe them. This is part of the process, she assured.

On day one we discussed that I am just this normal guy, which is what makes this thought a scary one - anyone could be me - but as we continue to work, I feel more like Charles Manson in one of his famous interviews than a "normal guy." The rock star mentality is working against the "all-american everyman" thought we started with. This is how the process works, though. I am having a blast - even this early on - playing through every scene because I know that I want to win each small battle, and Dan and Iris force me to use different tactics every time we play the scene. I can honestly say that every time we play each scene, there are different outcomes, and different discoveries. It is an incredible experience to have so many creative juices flowing, creating interesting moments with my scene partners, even though we are really still only doing table work, but on our feet.

I cannot wait to see where this play takes all four of us.

Journal \#6 - Sunday, August 21, 2011 : 
I discovered more comparisons between Reach and Bundy today. Bundy also refused to give details about his first victims. This is an interesting comparison, and one that is probably linked to the creation of Bill Reach dramatically. I found another serial killer who I hadn't heard of before: Rodney Alcala, or "The Dating Game Killer." He received that nickname because of the fact that he appeared on - and won - The Dating Game in 1978, right in the middle of his crimes. He has also been dubbed "The Other Bundy" because his crimes are so similar to his (and he looked a lot like him). Alcala murdered between 50 and 130 women. He is on Death Row right now for five murders in California.

I am finding it difficult to get pictures of actual serial killer's victims because a lot of pseudonyms are used, and the pictures are mostly in black and white given the era when serial killing was in its heyday.

I also put together a complete list of all the victims that Reach talks about in the show. I thought it would be beneficial to have all the information that Blessing gives the actors about the killings in one place. I referenced this sheet multiple times throughout the production, and it helped me keep everything straight.

\section{William Reach's Victim List:}

PRE. Renee Michaels

a. Claims to have killed her before Cindy.

b. 18 years old

c. Met in a bar near home

d. Never seen her before

1. Cindy Lauterber

a. Stranger 
b. 18 years old

c. Pretty

d. Met in a mall in the middle of the day (called in sick to work).

e. "Magazine photographer" bit got her in the car.

f. Pulled a knife when she got into the car (acted as though the camera strap was stuck under the seat, and asked her to move the seat up).

g. Drove her to Sugar Lake (10 victims left there in total).

h. Got her out of the car and stabbed her 7 or 8 times.

i. Accidently cut own arm.

j. Raped her after she was dead.

k. Threw her down the hill after sex for the animals.

2. Not Discussed in the Play

3. Not Discussed in the Play

4. Not Discussed in the Play

5. Paula Milstrom

a. Met in a bar, and took her home.

b. Had consensual sex at home.

c. Stabbed her in her sleep.

d. Kept her in the apartment for 6 days before bringing her to Sugar Lake.

6. Not Discussed in the Play

7. Not Discussed in the Play

8. Not Discussed in the Play

9. Melanie Bryce

a. 16 years old.

b. Met in Edwardsville, 300 miles away from home.

c. Picked her and her friend (Gina Miller) up near their high school when they were hitchhiking in a rainstorm.

d. Dropped Gina off at her house because she looked messy and unimportant; badly dressed.

e. Immediately pulled a gun, and made her get down out of sight, and then tied her hands behind her back with tape, and taped her mouth.

f. Drove her to an empty farmhouse owned by John Berthelsen 30 miles from home.

g. Drove Melanie 270 miles while she was alive and conscious.

h. Broke into the farmhouse and took her to the kitchen.

i. Tied her in a chair.

j. She gave oral sex.

k. Came in her mouth, and slit her throat with a fishing knife.

I. Cut off her head and put it in a plastic bag, and put it in the trunk of the car.

$\mathrm{m}$. Put the body in a garbage bag in the trunk of the car, cleaned up, and left for Sugar Lake. 
n. On the way, stopped to see a court-assigned therapist for the final session. Therapist said that real progress was being made.

10. Roberta Anson

a. Dumped at Sugar Lake

b. Forgot an ankle bracelet.

c. Came back for bracelet a few days later, during the day; saw all the bodies, and never dumped there again.

11. Not Discussed in the Play

12. Not Discussed in the Play

13. Not Discussed in the Play

14. Dianne McCusick

a. Killed victims 14,15 , and 16 over a period of 6 -hours, driving all night long.

b. Dianne McCusick

i. 20-year-old college student.

ii. Early Evening

iii. Stopped at a carnival.

iv. Offered to help her find her friends.

v. Lured her to the car with promise of drugs.

vi. Killed with a hammer as soon as she entered the car.

15. Beverly Flemming

a. Killed with a hammer.

b. See \#14.

16. Mary Lander

a. Killed with a hammer.

b. See \#14

17. Not Discussed in the Play

18. Not Discussed in the Play

19. Jeanette Perry

a. 10 years old

b. Found her alone at a convenience store near her school.

c. Grabbed her, took her around the corner, threw her in the car, and drove off.

d. Grabbed such a young girl because the compulsion to kill became too strong.

e. Although the court records say she was killed right away, this may not be true:

i. Lied to make the case simpler.

ii. Put a rope around her neck.

iii. Confessed all the killings to her.

iv. Told her the story, and then pulled on the loop hard, watching her blue eyes turn bluer, and die (her eyes are actually brown).

f. Buried her body and covered it with quicklime. 
One of the victims: Stabbed 10 times, strangled her with a nylon rope, and nearly severed her head from her body. Then raped her. Then cut off her head and took it home, putting it on the kitchen table. Stared at it. Then had sex with it. 


\section{LISTEN AND RESPOND - PART THREE: PROCESS}

If I had to name one professor that has taught me more practical implementation in the art of acting than any other, I would have to turn to Jerry McGonigle. Jerry took our graduate class through a series of Sanford Meisner training techniques, and though they seemed incredibly tedious while I was in the middle of them, they have had a profound effect on my approach as an actor. Jerry has taught me that as long as I am genuinely listening and responding, just knowing all the given circumstance of the play to that point and not doing anything to show them, then I am interesting to watch. He has constantly said that no character I could create can be more interesting than bringing myself on stage, and though it took some time to understand what he meant, I can now say that I agree with him.

The level of personalization that Jerry demanded was something I was uncomfortable with for a long time, but eventually came to not only trust, but to rely on to find any success with a character. What's astonishing is that, looking back on it all, Laura Hitt, our voice professor at WVU, was pushing me in the same direction that Jerry was all along. I had no idea of it at the time, but without that full body and voice connection, there can be no truthful character, which is what is always the goal.

That said, my approach to William Reach can be boiled down simply to this: through research, I did my best to find as much of William Reach inside myself as I could every night, and then, when onstage, I let everything else go, 
and just lived as truthfully as I could, listening and responding using the words that Lee Blessing wrote for me.

I tried to achieve this every night by going through a similar routine. When I arrived at the theatre, generally one to one-and-a-half hours before curtain, I would check my few props onstage, and then sit in my chair that I would inhabit for the majority of the play. From my seat, I would begin a vocal warm-up, mixing elements that I learned both at West Virginia University, and those I learned at Wayne State University, along with some nonsensical sounds in order to get the resonators opened up. Then I would look over all nineteen of my victims, whose pictures were already spread out over the interrogation table. I tried to visualize each woman as they looked in their small picture, and how they would have looked right before I, as Reach, murdered them. This helped put me a specific mindset of bloodlust. For Reach, thinking back on these murders would undoubtedly give him a rush because my research tells me that it does for the gross majority of serial killers. Thus, I needed to feel something inside me when I looked at these pictures every night.

From the chair, I would move to the bench in the back on the interrogation room. I would lie down on the bench and continue my vocal warm-up for a few minutes, soaking in whatever energy the theatre had for me that evening.

After I grabbed my handcuffs from the props closet, I would go backstage to continue my vocal warm-up, and to go over my lines. Every night I would have two specific speeches that I would go over for two different reasons. One, to make sure I remembered the words, and two, to get my images connected to my 
language. This was important for me because my monologue in scene seventeen is one giant picture that I needed to paint for the audience.

My approach to memorizing that monologue helped me in performance because I memorized each beat as a different image. Kara helped me with this dramatically. One night at the end of rehearsal, Kara had me lie on the ground with my eyes closed. She would say a line, and then I would repeat it until I felt comfortable with it. It took about thirty minutes to get through the entire monologue, but when it was done, I was practically memorized, and the images were popping like they absolutely needed to in order for the monologue to work on Dan.

Once the house opened up (at thirty minutes to curtain), I would head up to my dressing room, apply my light makeup, and get dressed in my bright orange jumpsuit. I would usually sit in silence for a good fifteen minutes before I headed back down to the stage. There, I would find a chair in the darkness and go over my motivations. I decided during tech week that the thing I wanted most in the world, as Reach, was to be remembered forever. I would repeat this desire to myself over and over again until I felt that I, Branden, had accepted that as my goal for the next couple hours.

A couple of other things that would go through my head during this tenminute session before the show began would be the victims. I would think back to the nineteen murders, and the feelings that were rushing through my body as I took their lives. Then I would think about the celebrity status I had achieved in the wake of the murders. My interview with Sixty Minutes would go through my head, 
as well as all the people wearing my t-shirts, and reading the books about me, none of them written from my perspective. These thoughts would help catapult me onto the stage every night. I felt emotionally present when this hour and a half long preparation would conclude with my first entrance.

Once I made that first entrance - as always happens with me - all doubts, fears, and butterflies that may have appeared seconds earlier, faded away immediately. At that point, it was simply a matter of listening and responding to Greg and Amy. Working with these two made that simple process seem easy because both were always present and open to anything I may have thrown their way.

The process I followed to play Reach was definitely different than what I would have attempted prior to Down the Road, but the freedom that the "listen and respond" approach demands was invigorating, and one I will use as I continue work in the professional world. I had a director in undergrad once say that we needed to rehearse the show until it couldn't go wrong, meaning that whatever happens in the moment is right. Without fully grasping what he meant then, I understand now how spot-on he really was: if you are genuinely listening and responding during a show, it does not matter what happens. As long as you respond truthfully then it is exactly what was "supposed" to happen. This idea frees me up as an actor because it allows all worries to melt away. That freedom is what I felt every single night that I took the stage as William Reach, and I have never had more fun on stage. 


\section{EVALUATION}

I would be lying if I said I was not curious how the audience would respond to the show. I was pleasantly surprised to discover that the audience, in

general, appreciated the performance (it is hard to "enjoy" Down the Road due its subject matter), and it turned out that I scared quite a few people. Though it was never my intention to scare anyone, I absolutely adored the fact that I had the power to scare with my acting. I have been told jokingly that I was "too convincing," usually by the older women in the audience. These remarks are always flattering, but what do they really mean? All they tell me is that I was able to live truthfully as this character of William Reach for an hour-and-a-half each night. In the end, that is the only conclusion I am aiming for.

I was able to find my own voice with Bill Reach that I hadn't really found up to that point. That is not to say I am not proud of any of my work that preceded Reach, it just means that I now understand what I need to do to find my real voice, and to truthfully connect with a character, no matter how despicable they may be. In fact, I learned that throwing out how good or bad a character might be is the best way to approach it. Reach did not think of himself as a bad person, so it was my duty as the actor playing Reach to not think of him as a bad person.

The positive reaction I received from playing Reach solidified the idea that if an actor steps on stage filled with the given circumstances, and then listens and responds truthfully, the audience will be as engaged as the actor. It is a 
simple idea that took me seven years of detailed work, and two degrees, to truly appreciate.

Aside from learning what it means to be an engaging actor, I also relearned how to have fun, which is something we tend to forget about through the grind of educational theatre. There was never a night when the proverbial curtain closed that I was not smiling because of the great time I had. Thanks to my two wonderful cast mates, and an excellent director who gave us the permission to be free and open to anything, every performance was different. Essentially, I learned that how one delivers lines is insignificant to why one delivers a line, and what they are trying to get from the other person. This fact, along with the confidence I had in my preparation and research into the role, gave me the feeling that anything I did onstage was acceptable. Now, of course, Kara would give me notes that would correct that thinking, but she always suggested something that would better help me, as Reach, get what I wanted from Dan and Iris.

The lessons I have learned playing Bill Reach have affected every performance I have done since, and I truly feel like I am better off as an actor after having played one of fiction's most heinous characters. 


\section{BIBLIOGRAPHY}

\section{Books}

Blessing, Lee. Down the Road. New York: Dramatists Play Service, 1991. Print.

Knowlton, Janice, and Michael Newton. Daddy Was the Black Dahlia Killer. New York: Pocket, 1995. Print.

\section{Website Links}

"Confessions Of A Serial Killer Henry Lee Lucas (Part 2)." YouTube. YouTube, 14 Feb. 2007. Web. <http://www.youtube.com/watch?v=i2XjlaHD1IU>.

"Confessions Of A Serial Killer Henry Lee Lucas (Part 3)." YouTube. YouTube, 14 Feb. 2007. Web. <http://www.youtube.com/watch?v=DXKs3hPnbQo>.

Crime Library. Web. <http://www.trutv.com/library/crime/index.html>.

"David Letterman - Bradley Cooper Interview." YouTube. YouTube, 16 Mar.

2011. Web. <http://www.youtube.com/watch?v=WM7hmke5XpM>.

"Ed Kemper Interview 1984 (1/2)." YouTube. YouTube, 17 June 2011. Web. <http://www.youtube.com/watch?v=tTnEY8y-p7M>.

"Ed Kemper Interview 1984 (2/2)." YouTube. YouTube, 17 June 2011. Web. $<$ http://www.youtube.com/watch?v=pmFuNBgFue4>.

"Ed Kemper Speaks About His Murders." YouTube. YouTube, 17 July 2009.

Web. <http://www.youtube.com/watch?v=_GSPFAd5XO8>.

"Exclusive Interview with BTK Killer." YouTube. YouTube, 25 Oct. 2009. Web. <http://www.youtube.com/watch?v=ZXa_YreEFEs>.

"Jeffrey Dahmer Interview - Extended Footage." YouTube. YouTube, 27 Nov. 2008. Web. <http://www.youtube.com/watch?v=ErB0R4wIB64>. 
"Jeffrey Dahmer Part 1 of 5." YouTube. YouTube, 02 Dec. 2007. Web. $<$ http://www.youtube.com/watch?v=gwYbiWdassl>.

"The Night Stalker Serial Killer Richard Ramirez Interview." YouTube. YouTube, 13 July 2010. Web. <http://www.youtube.com/watch?v=F4u2F1lh6Fc>. "Richard Ramirez Part 1 of 5." YouTube. YouTube, 02 Dec. 2007. Web. $<$ http://www.youtube.com/watch?v=7nAfxZlu6AA>

"Serial Killer Rodney James Alcala on the Dating Game." YouTube. YouTube, 10 Mar. 2010. Web. <http://www.youtube.com/watch?v=9Uf95INZmWl>.

"Ted Bundy Interview - Part 1 of 6." YouTube. YouTube, 20 Feb. 2010. Web. $<\mathrm{http}: / / w w w$. youtube.com/watch?v=x5FbEqoUQ9A $>$.

"Ted Bundy." Wikipedia. Wikimedia Foundation, 22 Mar. 2012. Web. <http://en.wikipedia.org/wiki/Ted_Bundy>.

West, Vanessa. "Crime Scene Photos." The Criminal Mind. Web. <http://vanessawest.tripod.com/crimescenephotos.html>. 